\title{
Empirical Analysis of Joint Impact of Enterprise Risk Management and Corporate Governance on Firm Value
}

\author{
Ananth Rao, * \\ aDubai Business School, University of Dubai, Dubai, United Arab Emirates, arao@ud.ac.ae \\ ${ }^{*}$ Corresponding author.
}

Received: 16 June 2017, revised: 4 September 2017, accepted: 7 September 2017, published: 9 April 2018

\begin{abstract}
This paper analyzes simultaneity and endogeneity of ERM and Corporate Governance. It assesses quantitative relationship between Corporate Governance, ERM and value of the firm. The research results provide quantitative justifications for the boards to make investments in ERM and Corporate Governance initiatives for improved shareholder wealth. 3SLS-IV system modelling was applied on 2004-11 data of Gulf Cooperation Council financial institutions. Our research confirms the simultaneity and endogeneity of Corporate Governance, ERM and Firm Value determinants. Firm value is jointly and positively impacted by ERM \& Corporate Governance initiatives although the impact was less significant. Unexpectedly, ERM initiative was significantly and negatively impacted by determinants such as intangibility, and profitability. Firm size was the only determinant that showed significant and positive impact on firm value. Relative to UAE the corporate governance mechanism was active in Bahrain, Saudi Arabia, Kuwait and Oman firms. Further, the existence of audit committees in the GCC firm's boards and ERM adoption significantly positively impacted the corporate governance by $3.42 \%$ and $1.7239 \%$ respectively.
\end{abstract}

Keywords: Corporate Governance, Enterprise Risk Management, Firm Value, Simultaneity, Endogeneity, Gulf Cooperation Council (GCC) economies.

JEL codes: C15, C21, C51, D57, F30, G21, G32, G34, K22, L21, M31, M41, N25, O16

\section{INTRODUCTION}

A recent survey of global CEOs found that enterprise risk management (ERM) is a priority among more than one-third of CEOs (39 percent strongly agree) and their boards (38 percent strongly agree) (PwC 2008). Analysis of more than 1000 directors serving on the boards of top 2000 publicly traded companies through 2009 Annual Corporate Directory survey revealed that, about 60 percent of the board members considered "Unknown risks" as their daunting task, and about 56 percent emphasized that the board of directors (BOD) must invest much more time and focus on risk management than in the past (PwC 2010). Creatively mitigating risk is critical to maximizing shareholder value and corporate governance (CG) requires firms to address various risk issues integratedly and simultaneously through enterprise risk management (ERM) ${ }^{1}$ processes (Yilmaz \& Flouris, 2010). There is a need to shift thinking from CG as a cost or risk mitigation effort, to $C G$ as a strategic goal that brings in new revenues (Pohle \& Hittner, 2008).

Corporate executives are "justifiably uncomfortable making a deeper commitment to ERM initiatives without a clear and quantifiable business case" (Sim Segal (2011)). Rightly so, Niamh and Solomon (2008) in their overview of corporate governance, accountability and mechanisms of accountability, placed risk management (as one of the mechanisms of accountability) and undertaking studies in developing economies (as a part of globalization) on the frontiers of CG research.

Academics and industry commentators argue that ERM and CG benefit firms by decreasing earnings and stock price volatility, reducing external capital costs, increasing risk awareness, increasing capital efficiency, and creating synergies between different risk management activities (Miccolis and Shah, 2000; Gumming and

${ }^{1}$ ERM is synonymous with integrated risk management (IRM), holistic risk management, enterprise-wide risk management, and strategic risk management. For consistency, we use the acronym ERM throughout this study.

https://doi.org/10.30585/irabml.v1i1.66

(C) 2018 the Authors. Production and hosting by Avicenna FZ LLC. on behalf of Dubai Business School, University of Dubai - United Arab Emirates. This is an open access article under the CC BY-NC license. 
Hirtle, 2001; Lam, 2001; Meulbroek, 2002; Klefmer, Lee, and McGannon, 2003; Beasley, Clune, and Hermanson, 2005; Beasley, Pagach, and Warr, 2008).

\subsection{Research problem and questions}

Empirical evidence regarding the joint quantitative impact of ERM and CG on firm value is scarce thus limiting their adoption by firms ${ }^{2}$. This research paper therefore possibly is the first empirical research in Gulf Cooperation Council (GCC) 3 to develop a conceptual framework to address the joint impact of ERM and CG initiatives on firm value, and validate the framework with a set of empirical data of GCC economies.

\subsubsection{Justification of the Research}

The rationale is that BOD of profit maximizing firms considers implementing ERM and CG programs jointly only if these initiatives increase expected shareholder wealth by increasing firm value.

\subsubsection{Organization of the paper}

The research study is structured as follows. Section two develops a conceptual framework to answer the question why in theory ERM \& CG jointly add value to the firm together with relevant literature review. Section three develops a set of indicators of ERM \& CG to quantify their joint impact on firm value. Section four applies the conceptual framework empirically to a sample data of fast emerging economies in GCC, discusses the methodology, and analyzes results. Section five concludes the research with avenues for further research.

\section{LITERATURE REVIEW}

\subsection{Value relevance of Corporate Governance Initiatives}

The value relevance for $C G$ from an agency theory perspective is that adequate monitoring or control mechanisms need to be established to protect shareholders from management's conflict of interest (Fama and Jensen, 1983). Hermalin and Weisbach (1998) showed that board structure is partly a function of the bargaining process between the chief executive officer (CEO), and the board. Theoretical work by Raheja (2005) and Harris and Raviv (2008), show that firm performance has a direct influence on the firm's information environment, profit potential, and the opportunity cost of outside directors in the BOD, all of which are factors that may affect the corporate governance. Hence existence of risk and audit committees are the strategic tools/mechanisms imposed by the BOD to govern the risk exposure at the firm level.

\subsection{Value relevance of Corporate Governance - ERM initiatives}

ERM evolved from a narrow, insurance based view to a holistic and encompassing view of risk. In September 2004, the Committee of Sponsoring Organizations of the Treadway Commission (COSO) provided a model framework for ERM. That framework defines ERM as "a process, monitored by an entity's BOD, management and other personnel, applied in strategy setting and across the enterprise, designed to identify potential events that may affect the entity, and manage risks to be within its risk tolerance, to provide reasonable assurance regarding the achievement of entity objectives." Nocco and Schulz (2006) argue that ERM is beneficial to most firms because it allows them to manage risks in a manner that avoids costly left-tail outcomes. Companies adopting ERM cited "the influence of the risk manager (61\%), encouragement from the BOD $(51 \%)$, and compliance with Toronto Stock Exchange (TSE) guidelines (37\%)" as the key factors causing their adoption of ERM (Kleffner et al. (2003). Liebenberg and Hoyt (2003) used Chief Risk Officer (CRO) appointments to examine the determinants of ERM adoption. Beasley et al. (2005) show that the presence of a CRO, board independence, managerial involvement, firm size and auditor type is associated with a greater stage of ERM adoption. Pagach and Warr (2007) show that firms that are more leveraged, have more volatile earnings and exhibit poorer stock market performance, are more likely to initiate an ERM program. Additionally, they find that ERM is used for reasons beyond basic risk management, including offsetting CEO risk taking incentives and seeking improved operating performance. These studies indicate that, as the first potential source of value of CG from ERM, firms that engage in ERM are able to better understand the aggregate risk inherent in different business activities, which provides the firms with a more objective basis for resource allocation and improved firm value.

\footnotetext{
2 Boatright (2011) address ERM and CG as complementary tools.

${ }^{3}$ GCC countries include United Arab Emirates, Oman, Kingdom of Saudi Arabia, Kuwait, Bahrain and Qatar.
} 
A second potential source of value of CG from ERM initiative arises due to improved information about the firm's risk profile. Outsiders are more likely to have difficulty in assessing the financial strength and risk profile of opaque firms that are highly complex both financially and operationally. ERM enable these opaque firms to better inform outsiders of their risk profile and serve as a signal of their commitment to risk management. By improving risk management disclosure, ERM is likely to reduce the expected costs of regulatory scrutiny and external capital (Meulbroek, 2002). Additionally, for banks, insurers and large business houses, the major rating agencies have put increasing focus on risk management and ERM specifically as part of their financial review. This is likely to provide additional incentives for these firms to consider ERM programs, and also suggest a potential value implication to the existence of ERM programs in these firms. For instance, in October 2005, Standard \& Poor's announced that with the emergence of ERM, risk management will become a separate, major category of its analysis. In February 2006, A.M. Best released a special report describing its increased focus on ERM in the rating process. Smithson and Simkins (2005) provide a thorough review of the literature regarding the value relevance of risk management. Although these studies considered specific types of hedging activity, very few studies find evidence of relationship between CG, ERM and value of the firm (Allayannis and Weston, 2001; Guay and Kothari, 2003), which is the purpose of this research paper.

\section{CONCEPTUAL FRAMEWORK}

From the perspective of CG, the key elements of successful ERM programs are (a) comprehensive and transcendent risk management that operates to avoid silos, and (b) senior level (preferably board level) involvement in risk management. It is the responsibility of the BOD and the senior management to define the firm's risk tolerance and to ensure that the firm's risk management framework includes detailed policies that set specific firms' activities that is consistent with its risk tolerance and capacity. In order to determine the overall risk tolerance, the $\mathrm{BOD}$ and senior management must have an understanding of risk exposures at three levels: at the level of system, at the level of the firm/enterprise, and at the transaction level. These aspects are conceptualized in the framework in figure.1. It is reasonable to posit that at the system level, the firm's BOD strategically formulates both (A) CG initiatives and (B) ERM initiatives as elements of CG. At the firm level, the top-management strategizes these initiatives through creating specific instruments such as Audit Committees, Risk committees, and induction of independent board members for ensuring effective CG. At the transaction level, the firm's operatives implement ERM initiatives to mitigate operation risk, liquidity risk, credit risk, leverage risk and capital risk that are faced by the firm. Together these three levels of activities effectively create firm value.

Figure.1 Conceptual Framework of CG and ERM Joint Impact on Firm Value

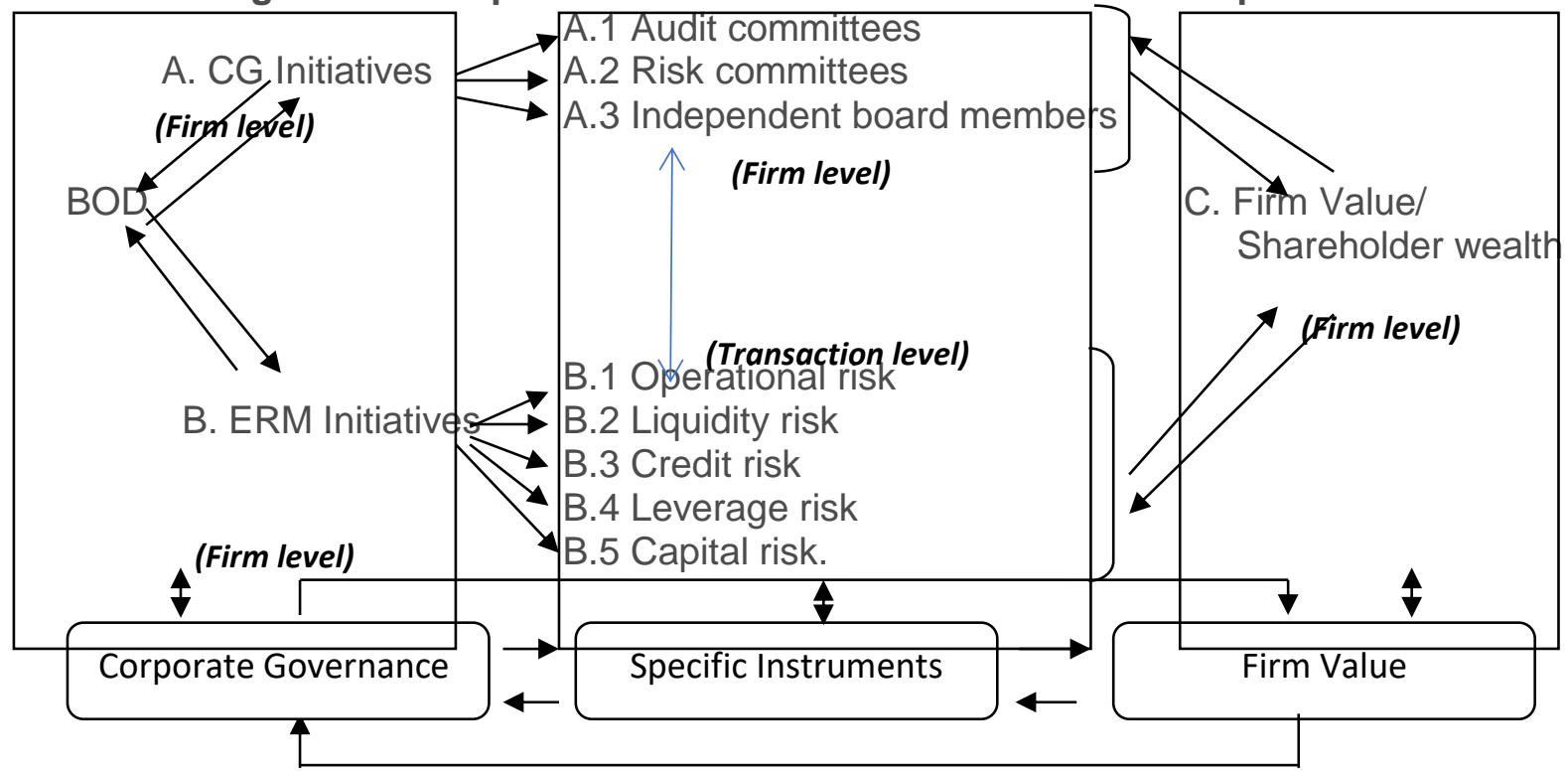

(System level)

\section{Research Hypotheses}

Consistent with the framework (Figure 1), this research answers the empirical research question of simultaneity and endogeneity issues in decision making by firm's BOD by specifically testing the following null research hypotheses $\left(\mathrm{RH}_{0}\right)$ : 
$\mathrm{RH}_{01}$ : ERM \& CG initiatives are not jointly undertaken by the firm. That is, BOD adopts CG \& ERM initiatives independently implying no simultaneity in formulating these initiatives.

RHo2: Firm value does not influence the BOD's strategic adoption of ERM \& CG joint initiatives. That is, there is independence between firm value and CG \& ERM initiatives implying there is no endogeneity in the BOD initiatives.

$\mathrm{RH}_{03}$ : Joint adoption of ERM \& CG initiatives do not improve Firm value (FV).

In addition to these three specific hypotheses, this research also identifies key significant determinants that influence ERM and CG initiatives for enhancing firm value.

\section{METHODOLOGY}

\subsection{Measuring ERM Initiatives}

Since ERM function is rarely observed in financial firms, and empirical evidence on ERM metric is scarce, we proxy ERM metric in this study as an indicator variable with ERM $=1$ implying adoption of ERM initiatives by the financial firms who have met any one of the following five conditions, and $E R M=0$ implying non-adoption of ERM initiatives.

\begin{tabular}{cll}
\hline$\#$ & \multicolumn{1}{c}{ Nature of condition } & \multicolumn{1}{c}{ What the condition reflects? } \\
\hline 1 & $\begin{array}{l}\text { If the financial firm has audit } \\
\text { committees in the BOD }\end{array}$ & $\begin{array}{l}\text { This condition reflects active BOD where, audit committee } \\
\text { monitors various risks of firms and reports to BOD for } \\
\text { undertaking control measures to mitigate risks strategically. }\end{array}$ \\
2 & $\begin{array}{l}\text { If the financial firm has derivative } \\
\text { products under assets } \\
\text { If the financial firm has derivative } \\
\text { products under liabilities } \\
\text { If the financial firm maintains a } \\
\text { positive reserve ratio of non- } \\
\text { performance loans to gross } \\
\text { loans } \\
\text { If the financial firm has Tier-1 } \\
\text { Capital Ratio greater than } 4 \% .\end{array}$ & $\begin{array}{l}\text { Thestruments such as derivatives (like Options, Futures, SWAPs, } \\
\text { off balance sheet commitments) to manage financial and } \\
\text { operational risks of the financial firm. }\end{array}$ \\
& $\begin{array}{l}\text { This condition reflects pro-active action to manage credit risk. } \\
\text { Higher the reserve ratio lower are the credit risks in the } \\
\text { financial firm. }\end{array}$ \\
& $\begin{array}{l}\text { In this condition, positive tier-1 capital adequacy as per the } \\
\text { stipulations from the GCC Central Banks, imply commitment of } \\
\text { management to potentially employ risk management practices } \\
\text { to mitigate capital risk of the firms. }\end{array}$ \\
\hline
\end{tabular}

\subsection{Measuring Firm Value-Tobin's $Q$}

Consistent with the general practice in the corporate finance literature we use Tobin's $Q$ as a proxy for firm value (Boone et al (2007), Linck et al. (2008), and Lehn et al. (2009)). Lang and Stulz (1994) explain that Tobin's $Q$ dominates other performance measures (e.g., stock returns and accounting measures) because, unlike other measures, Tobin's $Q$ does not require risk adjustment or normalization. Furthermore, because Tobin's $Q$ reflects market expectations, it is relatively free from managerial manipulation (Lindenberg and Ross, 1981). Cummins, Lewis, and Wei (2006) contend that Tobin's $Q$ is appropriate for finance companies because the book value of their assets is a much closer approximation of replacement costs than would be the case for nonfinancial firms. We measure Tobin's $Q$ as the market value of equity plus the book value of liabilities divided by the book value of assets.

\subsection{Measuring CG}

Good CG requires the board to constantly monitor the firm to ensure growth in the firm value to protect the interests of the shareholders. Yermack (1996) used factors such as board size and existence of audit committees to measure the impact on Tobin-Q. We measure CG as the number of members in the BOD.

We test the simultaneity and endogeneity hypotheses through simultaneous equation system using 3SLS Instrumental Variable (IV) Technique ${ }^{4}$. The instrument variables generally include all of the independent variables in the system of equations and may include any other variable as well. In this simultaneous equation system, the right-hand side regressors are allowed to be the endogenous variables as well. In one equation, ERM is allowed to depend on firm value, $C G$ and other control variables while in other equations, CG is allowed to depend on firm value and other control variables. 3SLS-IV does not assume cross equation correlation of

\footnotetext{
${ }^{4}$ Endogeneity is one of the most major challenges in econometric analysis in management and much of social Sciences. Endogeneity can be caused by three circumstances: Omitted Variables, Measurement Error, and Simultaneity. Endogeneity issue is generally addressed by applying Instrumental Variables Regression.
} 
error terms and it uses a set of instrumental variables for estimation purposes. In the next section, the conceptual framework (figure 1) is evaluated by system equations modeling. The research hypotheses are empirically tested with a set of data of financial institutions in GCC which are fast emerging economies characterized by much activity in CG, and ERM during 2004 and thereafter.

\subsection{Empirical Model}

The conceptual framework (figure 1) is modelled through the simultaneous system of equations of the form:

Where:

$$
Y_{i t}=X_{i t} \beta_{i t}+\varepsilon_{i t}, i=1, \ldots \ldots . m,
$$

$Y_{i}$ represents $T x 1$ vector of equation $i=$ equation number 1 to 3

$X_{i}$ is a $T \times k_{i}$ matrix of determinants in each of the three system equations

$\beta_{i}$ is a $k_{i \times 1}$ vector of system coefficient in each of the three system equations

$\varepsilon_{\mathrm{i}}$ are $T \times 1$ vector of errors in each of the three system equations, and

$\mathrm{t}=1, \ldots, \mathrm{T}^{5}$.

\section{Equation 1 - ERM Determinants \& Hypotheses}

The first equation $E R M_{t}$ in the system of equations is modeled as below:

$$
\begin{aligned}
& E R M_{t}=a_{11}+b_{12} F V_{t}+b_{13} C G_{t}+b_{14} L L R_{t}+b_{15} C A R_{t}+b_{16} R O A A_{t}+b_{17} M_{t}+b_{18} D_{t}+b_{19} \\
& \text { Size }_{t}+b_{1,10} D E_{t}+b_{1,11} \text { Opaque }_{t}+b_{1,12} \text { CVNI }_{t}+b 1,13 \text { Slack }_{t}+b_{1,14} \text { Diverse }_{t}+\varepsilon_{1 t}
\end{aligned}
$$

Firm value $\left(F_{\mathbf{t}}\right)$ and $\mathbf{C G}_{\mathrm{t}}$ are endogenous and discussed in equations 2 and 3 . Other right hand side variables characterize risk features, financial features, asset features, market features and firm features and are discussed below.

Loan loss reserves $\left(\mathbf{L L R}_{\mathbf{t}}\right)$ : represent credit risk. Higher loan reserves imply conservative behavior of the firm's management to overcome credit risk. Hence hypothesis of positive sign on the estimated coefficient is plausible.

Tier-1 Capital (CAR $\mathbf{t})$ : represents capital risk. Higher tier-1 capital implies a conservative regulatory requirement to overcome capital risk. Hence hypothesis of positive sign on the estimated coefficient is plausible.

Profitability $(\mathbf{R O A A})$ : Profitability is measures as return on average asset. This determinant represents financial characteristics of the firms. The sign on this determinant is mixed. Positive sign implies firms have resources to implement ERM initiatives. Negative sign implies that adoption of ERM entailed significant capital expenditure resulting in reduced profitability.

Market-Book $\left(\mathrm{MB}_{\mathrm{t}}\right)$ ratio: This determinant represents market characteristics of banks. A positive sign is expected on the estimated coefficient representing the fact that investors value favorably the firms adopting ERM as risk management strategy.

Duration Gap ( $\left(\mathrm{DG}_{\mathrm{t}}\right)^{6}$ : A positive sign on this coefficient is expected signifying that the banks adopting duration gap measures represent actively participating in ERM activities.

Size $e_{t}$ Firm size is measured by the natural log of the book value of assets. Survey evidence suggests that larger firms are more likely to engage in ERM because they are more complex, face a wider array of risks, and have the institutional size to support the administrative cost of an ERM program (see, e.g., Colquitt, Hoyt, and Lee, 1999; Hoyt, Merkley, and Thiessen, 2001; Beasley, Clune, and Hermanson, 2005; Standard \& Poor's, 2005).

Leverage $\left(D E_{t}\right)$ : Leverage is measured as the ratio of liability to total equity $(D: E)$. Firms engaging in ERM may have lower financial leverage if they have decided to lower their probability of financial distress by decreasing financial risk. However, firms may decide that as a result of ERM they are able to assume greater financial risk. Accordingly, Pagach and Warr (2010) posit that the relation between ERM adoption and leverage is unclear.

\footnotetext{
${ }^{5}$ Data collection is limited to the 8-year period from 2004 to 2011 in BANKSCOPE database (as the earliest evidence of ERM activity in GCC is in 2004). This sample comprised of 160 financial institutions that operated in any year during the 8-year period.

${ }^{6}$ Measurement of $D G_{t}$ is explained in Table 1.
} 
Opaquet: Pottier and Sommer (2006) explain that relatively "opaque" firms are those that are harder for outsiders to evaluate. Liebenberg and Hoyt (2003) argue that firms that are relatively more opaque should derive greater benefit from ERM programs that communicate risk management objectives and strategies to outsiders. Pagach and Warr (2010) hypothesize that ERM adoption is related to the opacity of a firm's assets because assets that are relatively more opaque are more difficult to liquidate in order to avert financial distress. We measure opacity as the ratio of intangible assets to the book value of total assets \& hypothesize a positive relation between opaque and ERM, due to the fact that more opaque firms have illiquid asset structure and thus are more prone to enterprise risk exposure.

CVNIt: is the coefficient of variation of net income (NI). This determinant represents risk characteristics. Firms that are relatively more volatile are likely to benefit from the effects of an ERM program. However, firms that have adopted ERM programs are likely to experience lower volatility of stock returns or earnings. Thus, the direction of the relation is ambiguous.

Slack $\mathbf{k}_{\mathbf{t}}$ (Liquidity): Slack implies financial liquidity and is measured as the ratio of cash and marketable securities to total assets. ERM firms may have higher levels of financial slack due to an emphasis of risk management on reducing the probability of financial distress. ERM users may also be able to reduce the level of financial slack because of improved risk management (Pagach and Warr (2010)). Thus, the direction of the relation is ambiguous.

Diverse $_{t}$ (Diversification): Diversification in business is also likely to affect whether a firm adopts an ERM program or not. Theory suggests that diversification is associated with both costs and benefits. On the one hand, diversification may be performance enhancing due to the benefits associated with scope economies, larger internal capital markets, and risk reduction (Lewellen, 1971, Teece, 1980). On the other hand, diversification may reduce performance if it exacerbates agency costs and leads to inefficient crosssubsidization of poorly performing businesses (Easterbrook, 1984; Berger and Ofek, 1995) and thus increases potential for ERM. To control the effect of diversification on ERM, we use a dummy variable (DIVERSE) equal to 1 for firms that report diversified operations. We expect a mixed sign relation between diversification and ERM.

Equation 2 - Firm Value (FV or Tobin's Q) Determinants \& Hypotheses

The second equation $\mathrm{FV}_{\mathrm{t}}$ in the system is modeled as below:

$$
\begin{aligned}
& F_{t}=\quad a_{21}+b_{22} C G_{t}+b_{23} \text { ERM }_{t}+b_{24} \text { Growth }_{t}+b_{25} \text { ROAA }_{t}+b_{26} \text { DIVPMT }_{t}+b_{27} \\
& D E_{t}+b_{28} \text { Size }_{t}+b_{2,9} \text { Efficiency } \\
& t+b_{2,10} \text { MB }_{t}+\varepsilon_{2 t}
\end{aligned}
$$

Governance $\left(\mathbf{C G}_{\mathrm{t}}\right)$ : This is an endogenous variable in $\mathrm{CG}$ equation. Good governance requires the board to constantly monitor the firm to ensure growth in the firm value to protect the interests of the shareholders. We measure CG as the number of members in the BOD. A positive sign is expected between the firm value and CG.

ERM $_{\mathbf{t}}$ : ERM is an endogenous variable in the system.

Growth $\mathrm{t}_{\mathrm{t}}$ : Allayannis and Weston (2001) control for the effect of growth opportunities on Tobin's $\mathrm{Q}$ using the ratio of R\&D expenditure to sales, or capital expenditure to assets. Due to the missing data for the majority of sample firms, historical yearly asset growth is used as a proxy for future growth opportunities. A positive relation is hypothesized between asset growth and Tobin's $Q$.

Profitability $\left(\mathbf{R O A A}_{\mathbf{t}}\right)$ : It is quite natural that profitable firms are likely to trade at a premium. To control for firm profitability, return on average assets (ROAA) is included in the model. ROAA is calculated as net income divided by average asset in $t$ and $t-1$. We expect a positive relation between ROAA and Tobin's $Q$.

Dividend payment (DIVPMT ${ }_{t}$ ): Following Lang and Stulz (1994), dividend payment indicator is included that equals 1 if the firm paid a dividend in the current year. On the one hand, investors may view a disbursement of cash in the form of a dividend as a sign that the firm has exhausted its growth opportunities. If this holds then the payment of dividends will negatively affect firm value. On the other hand, to the extent that dividends reduce free cash flow that could be used for managerial perquisite consumption, the payment of dividends is expected to positively affect firm value. Thus, the expected sign is ambiguous.

Leverage $\left(D E_{t}\right)$ : To control for the relation between capital structure and firm value we include a leverage variable that is equal to the ratio of the book value of liabilities to the market value of equity. On the one hand, financial leverage enhances firm value to the extent that it reduces free cash flow that might otherwise have 
been invested by managers with self-interest in suboptimal projects (Jensen, 1986). On the other hand, excessive leverage can increase the probability of financial distress and cause the firm's owners to bear financial distress costs. Thus, the predicted sign on this variable is ambiguous.

Sizet: It is important to control size in the analysis as ERM indicator which is endogenous may proxy for firm size. Large firms are more likely to have ERM programs in place (Liebenberg and Hoyt, 2003). On the other hand, Lang and Stulz (1994) and Allayannis and Weston (2001) find a significant negative relation between size and firm value. We use natural log of assets to control for size-related variation in Tobin's $Q$. Thus, the predicted sign on this variable is ambiguous.

Efficiency $y_{t}$ : Earlier studies used a variety of cost efficiency measures as performance measures $(\mathrm{He}$, Sommer and Xie (2011)). We derive constant returns to scale cost efficiency scores from stochastic frontier efficiency modelling. The predicted sign on this variable is ambiguous. On the one hand, cost efficiency could enhance firm value which is plausible. On the other hand, excessive cost efficiency can decrease non-implementation of potential growth opportunities available to firms due to focus on cost efficiency. Thus, the predicted sign on this variable is ambiguous.

Market-Book $\left(\mathrm{MB}_{\mathrm{t}}\right)$ ratio: This determinant represents market characteristics of financial institutions. A positive sign is expected on the estimated coefficient representing the fact that investor views the financial institutions with a favorable MB ratio as higher performing firm. This variable is measured as Market price of the firm's stock to Equity. A positive sign is hypothesized.

\section{Equation 3 - Corporate Governance Determinants \& Hypotheses}

The third equation $\mathrm{CG}_{t}$ in the system is modeled as below:

$$
\mathrm{CG}_{\mathrm{t}}=\mathrm{a}_{31}+\mathrm{b}_{32} \text { LIST }_{\mathrm{t}}+\mathrm{b}_{33} \mathrm{AC}_{\mathrm{t}}+\mathrm{b}_{34} \text { Growth }_{\mathrm{t}}+\mathrm{b}_{35} \mathrm{FV}_{\mathrm{t}}+\mathrm{b}_{36} \mathrm{ERM}_{\mathrm{t}}+\mathrm{b}_{37} \text { DIVERSE }_{\mathrm{t}}+\varepsilon_{3 \mathrm{t}}
$$

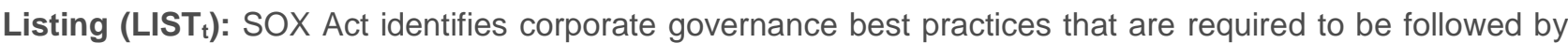
publicly listed companies. Hence a positive sign on the estimated coefficient is expected of the listed companies signifying good governance. LIST is an indicator variable equals 1 if the firm is listed in the local or regional financial market.

Audit Committee $\left(\mathbf{A C}_{\mathbf{t}}\right)$ : Consistent with SOX Act, number of members in the audit committee in the BOD features active corporate governance. A positive sign on the estimated coefficient is thus expected between $\mathrm{AC}$ and Corporate Governance.

Growth $_{\mathrm{t}}$ In terms of governance, active governance is concerned with stockholder value which requires firms to be growing concern at all times. Hence positive sign on the estimated coefficient is posited.

Firm Value $\left(\mathbf{F V}_{\mathrm{t}}\right)$ : is endogenous in the system of equations. Good governance requires the board to constantly monitor the firm to ensure consistent growth in the firm value to add value to the shareholders' wealth.

ERMt: This is also endogenous in the system.

DIVERSE $_{t}$ (Diversification): Generally, the firm's BOD desires a diversified business to mitigate enterprise risk to shareholders. On the other hand, diversification may also reduce firm's performance due to higher capital costs for diversification. To control the effect of diversification on Corporate Governance, we use a dummy variable (DIVERSE) equal 1 for firms that report multiple activities in its operations. We expect a mixed relation between diversification and Corporate Governance. Finally, 2008-year dummy is included in all the three equations as a control for the crisis year in GCC in general and UAE in particular (UAE-2008).

Table 1 summarizes the definition of variables and aforesaid hypotheses.

Table 1. Variable Definitions

\begin{tabular}{|c|c|c|c|c|}
\hline Eq.\# & $\begin{array}{l}\text { Coeffi } \\
- \\
\text { cient }\end{array}$ & $\begin{array}{l}\text { Variable } \\
\text { Name }\end{array}$ & Definition & $\begin{array}{l}\text { Hypothesis (Sign in } \\
\text { relation to the } \\
\text { function) }\end{array}$ \\
\hline \multirow[t]{3}{*}{ ERM } & & Risk -Mgmt & List of conditions indicated in the table under section 3.1 & Endogenous \\
\hline & $b_{12}$ & FV & Firm value measured through Tobin- $Q$ & + \\
\hline & $b_{13}$ & CG & $\begin{array}{l}\text { Corporate Governance measured as the existence of BOD in } \\
\text { the firm }\end{array}$ & + \\
\hline
\end{tabular}




\begin{tabular}{|c|c|c|c|c|}
\hline & $b_{14}$ & LLR & Loan loss reserve (Non-performing loant to Gross Loant) & + \\
\hline & $b_{15}$ & CAR & Capital adequacy ratio Tier-1 Capital to Total Capital & + \\
\hline & $b_{16}$ & ROAA & Net income $t \div$ Average of Assett and Assett -1 & $-/+$ \\
\hline & $b_{17}$ & MB & Market to book ratio $=$ Market price $t \div$ Equity $t$ & + \\
\hline & $b_{18}$ & DG & $\begin{array}{l}\text { Duration gap }=[\Delta \text { Interest earnings in } \mathrm{t} \& \mathrm{t}-1-\Delta \text { Interest } \\
\text { expenses in } \mathrm{t} \& \mathrm{t}-1] \div[\text { Total Assetst }]\end{array}$ & + \\
\hline & $b_{19}$ & Size & Natural logarithm of total assetst & + \\
\hline & $b_{1,10}$ & $\begin{array}{l}\text { LEVERAG } \\
\qquad \mathrm{E}\end{array}$ & Debt to equity (Liabilityt to Total Equityt) & $-/+$ \\
\hline & $b_{1,11}$ & Opaque & Intangible assets $t \div$ Assets $t$ & + \\
\hline & $b_{1,12}$ & CVNI & Coefficient of variation of net income $t$ & $-/+$ \\
\hline & $b_{1,13}$ & Slack & Cash \& Short-term investmentSt $\div$ Assetst & $-/+$ \\
\hline & $b_{1,14}$ & DIVERSE & Indicator $1=$ diversified activities, 0 otherwise & $-/+$ \\
\hline \multirow{10}{*}{$\begin{array}{l}\text { FV - } \\
\text { Tobin Q }\end{array}$} & & Firm value & (Market value of equity $t+$ Liability $t) \div$ Total Assetst & Endogenous \\
\hline & $b_{22}$ & CG & $\begin{array}{l}\text { Corporate Governance - Number of members in the BOD and } \\
\text { presence of various committee including Audit Committee }\end{array}$ & Endogenous \\
\hline & $b_{23}$ & ERM & List of conditions indicated in the table under section 3.1 & Endogenous \\
\hline & $b_{24}$ & Growth & $\left(\right.$ Asset $_{t}-$ Asset $\left._{t-1}\right) \div$ Asset $_{t-1}$ & + \\
\hline & $b_{25}$ & ROAA & Net income $t \div$ Average of Asset $t$ and Asset $t-1$ & - \\
\hline & $b_{26}$ & DIVPMT & $\begin{array}{l}\text { Dividend payment - Indicator variable } 1 \text { if the firm paid dividend } \\
\text { in the year or } 0 \text { otherwise. }\end{array}$ & $-/+$ \\
\hline & $b_{27}$ & $\begin{array}{l}\text { LEVERAG } \\
\qquad \mathrm{E}\end{array}$ & Debt to equity (Liability to Total Equityt) & $-/+$ \\
\hline & $\mathrm{b}_{28}$ & Size & Natural logarithm of total assets $t_{t}$ & $-/+$ \\
\hline & $b_{2,9}$ & Efficiency & $\begin{array}{l}\text { Constant returns to scale efficiency measure obtained from } \\
\text { stochastic frontier analysis }\end{array}$ & $-/+$ \\
\hline & $b_{2,10}$ & MB & Market to book ratio $=$ Market price $t \div$ Equity ${ }_{t}$ & + \\
\hline \multirow[t]{7}{*}{ CG } & & Governance & $\begin{array}{l}\text { Corporate Governance - Number of members in the BOD and } \\
\text { presence of various committee including Audit Committee }\end{array}$ & $\begin{array}{l}\text { Endogenous in the } \\
\text { System }\end{array}$ \\
\hline & $b_{32}$ & LIST & $\begin{array}{l}\text { Indicator variable }=1 \text { if listed in the local/regional financial } \\
\text { market }\end{array}$ & + \\
\hline & $b_{33}$ & $\mathrm{AC}$ & Number of members in the audit committee & + \\
\hline & $b_{34}$ & Growth & $\left(\right.$ Asset $_{t}-$ Asset $\left._{t-1}\right) \div$ Asset $_{t-1}$ & + \\
\hline & $b_{35}$ & Firm value & (Market value of equity $t+$ Liability $\left._{t}\right) \div$ Total Assets $t$ & Endogenous \\
\hline & $b_{36}$ & ERM & List of conditions indicated in the table under section 3.1 & Endogenous \\
\hline & $b_{37}$ & DIVERSE & Indicator 1=diversified activities, 0 otherwise & + \\
\hline
\end{tabular}

Preliminary Results

Summary statistics of the variables used in the study are reported in Table 2.

Table.2 Descriptive Statistics

\begin{tabular}{lrrr}
\hline \multicolumn{1}{c}{ Variables } & \multicolumn{1}{c}{ Mean } & Std. Dev & Skewness \\
\hline 2008 & 0.125 & 0.331 & 2.266 \\
LIST & 0.659 & 0.474 & -0.672 \\
BAHRAIN & 0.253 & 0.435 & 1.137 \\
KSA & 0.989 & 0.299 & 2.685 \\
KUWAIT & 0.165 & 0.371 & 1.805 \\
OMAN & 0.121 & 0.326 & 2.324 \\
UAE & 0.264 & 0.441 & 1.072 \\
QATAR & 0.099 & 0.299 & 2.685 \\
DIVERSE & 0.319 & 0.466 & 0.778 \\
BOD & 6.846 & 6.549 & 0.898 \\
AC & 0.736 & 1.406 & 1.543 \\
GGL & 21.04 & 48.089 & 4.081 \\
NPL-GL & 7.817 & 13.475 & 3.948 \\
TIER1-CAP & 19.304 & 15.435 & 5.352
\end{tabular}




\begin{tabular}{lrrr} 
ROAA & 2.852 & 7.075 & -1.015 \\
DIV.PAYOUT & 43.191 & 51.474 & 6.793 \\
PB & 2.11 & 2.39 & 6.678 \\
TOBIN-Q & 2.083 & 24.489 & 24.47 \\
ERM & 0.757 & 0.429 & -1.197 \\
SLACK & 0.306 & 0.237 & 1.229 \\
DG & 0.028 & 1.966 & 0.185 \\
CRSESE & 0.226 & 0.162 & 1.701 \\
LNTA & 14.818 & 1.777 & -0.189 \\
CVNI & 0.953 & 3.807 & 0.947 \\
LEVERAGE & 0.735 & 0.227 & -1.586 \\
DE & 12.051 & 117.238 & 16.639 \\
OPAQUE & 0.014 & 0.022 & 5.259 \\
UAE2008 & 0.033 & 0.179 & 5.228 \\
\hline
\end{tabular}

As generally expected, most of the variables are positively skewed and few are negatively skewed indicating non-normality of the set of determinants in the system of equations.

Table 3 presents the correlation matrix of all the determinants in the system of equations. The general lack of high correlation between the independent variables suggests that Multicollinearity is not a problem in this study.

Table 4 shows the distribution of financial institutions in the GCC used in this study.

Table 4. Percentage Distribution of Financial Institutions (FI) (Total \# 160 in GCC)

\begin{tabular}{lccccccc}
\hline Country & NBFC & CB & IB & $\begin{array}{l}\text { Total } \\
\text { FI }\end{array}$ & ID & Listed & BOD \\
\hline Bahrain & 38 & 25 & 41 & 31 & 26 & 19 & 30 \\
KSA & 13 & 10 & 10 & 10 & 13 & 11 & 11 \\
Kuwait & 33 & 17 & 18 & 20 & 30 & 27 & 20 \\
Oman & 8 & 12 & - & 8 & 4 & 10 & 11 \\
UAE & 4 & 26 & 20 & 22 & 21 & 25 & 19 \\
Qatar & 4 & 10 & 10 & 9 & 6 & 8 & 9 \\
Total & 14 & 56 & 30 & 100 & 28 & 58 & 75 \\
\hline
\end{tabular}

Index:

NBFC: Non-Banking Finance
Companies
CB: Commercial banks
IB: Islamic Banks
FI: Financial Institutions

ID: FI whose operations are Internationally diversified

Listed: FI who are listed on country's stock exchanges BOD: Fl who were governed by BOD

FI: Financial Institutions

Out of 160 sample financial institutions in the GCC, $31 \%$ were in Bahrain followed by $22 \%$ in UAE, and $20 \%$ in Kuwait. $56 \%$ of financial institutions were commercial banks followed by $30 \%$ Islamic banks. $28 \%$ of the financial institutions were having diversified operations of which maximum diversification was seen in Kuwait $(30 \%)$ followed by Bahrain (26\%) and UAE $(21 \%)$ with Qatar and Oman being least diversified internationally. $58 \%$ of the financial institutions were listed on respective country's stock exchange, of which Kuwait had maximum listed financial institutions (27\%) followed by UAE (25\%), and Bahrain (19\%). Interestingly $75 \%$ of the financial institutions were being governed by BOD with Bahrain topping the list $(30 \%)$, followed by Kuwait $(20 \%)$, and UAE (19\%). This indicates that all listed financial institutions in GCC do not necessarily have BOD (for example Kuwait and UAE) while few of non-listed FI were also governed by BOD (for example Bahrain, Oman and Qatar). 
http://dx.doi.org/10.30585/irabml.v1i1.66

(c) 2018 the Authors. International Review of Advances in Business, Management and Law 1(2), 2018

Table 3 Correlation Matric of 3SLS Model Determinants

\begin{tabular}{|c|c|c|c|c|c|c|c|c|c|c|c|c|c|c|c|c|c|c|c|c|c|c|c|c|c|c|}
\hline & \\
\hline & LIST & BH & KSA & KW & OMAN & UAE & QATAR & DIVERSE & BOD & $A C$ & GGL & NPL-GL & TIER1 & ROAA & DIV & PB & $\mathrm{TQ}$ & SLACK & DG & CRSESE & LNTA & CVNI & LEV & $\mathrm{DE}$ & OPAQUE & UAE*8 \\
\hline 2008 & 0.045 & -0.021 & 0.055 & -0.031 & 0 & 0.011 & -0.038 & -0.024 & -0.002 & -0.027 & 0.214 & -0.056 & -0.053 & 0.109 & -0.04 & 0.074 & \begin{tabular}{|l|} 
\\
\end{tabular} & 0.064 & -0.02 & 0.069 & -0.02 & 0.02 & 0.066 & 0.134 & -0.073 & 0.471 \\
\hline LIST & 1 & 0.045 & 0.067 & 0.038 & 0.041 & -0.196 & 0.039 & 0.098 & 0.142 & 0.083 & 0.095 & -0.023 & 0.069 & 0.056 & 0.003 & 0.075 & \begin{tabular}{|l|} 
\\
\end{tabular} & 0.131 & 0.024 & -0.223 & -0.202 & 0.034 & -0.085 & -0.124 & 0.033 & 0.021 \\
\hline $\mathrm{BH}$ & & 1 & -0.251 & -0.141 & -0.15 & -0.228 & -0.146 & -0.059 & 0.273 & 0.245 & \begin{tabular}{|l|}
-0.088 \\
\end{tabular} & 0.324 & 0.029 & -0.35 & 0.057 & -0.14 & \begin{tabular}{|l|}
-0.17 \\
\end{tabular} & 0.398 & 0.106 & 0.201 & -0.156 & 0.016 & 0.028 & 0.086 & 0.112 & -0.079 \\
\hline KSA & & & 1 & -0.213 & -0.23 & -0.343 & -0.219 & -0.068 & 0.005 & -0.086 & -0.029 & -0.211 & -0.028 & 0.154 & -0.24 & 0.257 & \begin{tabular}{|l|} 
\\
\end{tabular} & 0.471 & -0.07 & 0.182 & 0.384 & -0.151 & 0.119 & -0.182 & -0.067 & -0.118 \\
\hline KW & & & & 1 & -0.13 & -0.194 & -0.124 & 0.347 & -0.162 & \begin{tabular}{|l|}
-0.263 \\
\end{tabular} & \begin{tabular}{|l|}
-0.101 \\
\end{tabular} & 0.177 & -0.096 & -0.09 & 0.028 & 0.261 & \begin{tabular}{|l|}
0.105 \\
\end{tabular} & -0.03 & 0.05 & 0.026 & 0.044 & 0.562 & 0.185 & -0.105 & -0.119 & -0.067 \\
\hline OMAN & & & & & 1 & -0.211 & -0.135 & -0.014 & 0.171 & \begin{tabular}{|l|}
0.3 \\
\end{tabular} & 0.038 & 0.006 & -0.002 & -0.01 & 0.157 & -0.08 & \begin{tabular}{|l|}
-0.08 \\
\end{tabular} & -0.22 & -0.08 & \begin{tabular}{|c|}
-0.338 \\
\end{tabular} & \begin{tabular}{|c|}
-0.379 \\
\end{tabular} & -0.081 & -0.025 & -0.042 & 0.027 & -0.073 \\
\hline UAE & & & & & & 1 & -0.199 & -0.024 & -0.361 & \begin{tabular}{|l|} 
\\
\end{tabular} & 0.178 & -0.117 & 0.113 & 0.138 & -0.17 & -0.23 & \begin{tabular}{|l|}
-0.29 \\
\end{tabular} & -0.53 & 0.008 & -0.036 & 0.023 & -0.138 & -0.17 & 0.284 & 0.024 & 0.344 \\
\hline QATAR & & & & & & & 1 & -0.132 & 0.156 & 0.264 & 0.067 & -0.083 & -0.049 & 0.075 & 0.317 & -0.07 & \begin{tabular}{|l|} 
\\
\end{tabular} & -0.12 & 0.006 & -0.102 & -0.046 & -0.083 & -0.124 & -0.075 & 0.026 & \begin{tabular}{|l|l} 
& -0.069
\end{tabular} \\
\hline DIVERSE & & & & & & & & 1 & -0.067 & -0.014 & -0.059 & 0.099 & -0.093 & -0.15 & 0.013 & 0.114 & 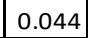 & 0.189 & 0.008 & 0.294 & 0.335 & 0.22 & 0.135 & -0.111 & -0.019 & -0.044 \\
\hline BOD & & & & & & & & & 1 & 0.834 & 0.043 & -0.026 & 0.079 & -0.07 & 0.052 & -0.05 & \begin{tabular}{|l|}
-0.07 \\
\end{tabular} & 0.141 & -0.04 & 0.004 & -0.089 & 0.089 & -0.009 & -0.023 & -0.048 & -0.114 \\
\hline$A C$ & & & & & & & & & & 1 & \begin{tabular}{l|l|}
0.018 \\
\end{tabular} & -0.022 & -0.049 & -0.12 & 0.217 & -0.09 & \begin{tabular}{|l|}
-0.07 \\
\end{tabular} & 0.049 & -0.08 & 0.016 & -0.039 & -0.097 & 0.006 & -0.04 & -0.013 & -0.146 \\
\hline GGL & & & & & & & & & & & 1 & -0.216 & 0.037 & 0.139 & -0.03 & 0.059 & \begin{tabular}{|l|}
0.105 \\
\end{tabular} & -0.2 & -0.04 & -0.067 & -0.145 & -0.027 & -0.149 & 0.1 & 0.011 & 0.155 \\
\hline NPL-GL & & & & & & & & & & & & 1 & 0.279 & \begin{tabular}{|l|}
-0.51 \\
\end{tabular} & -0.02 & 0.001 & \begin{tabular}{|l|}
-0.03 \\
\end{tabular} & 0.136 & 0.152 & \begin{tabular}{|c|}
-0.178 \\
\end{tabular} & -0.443 & 0.164 & -0.367 & -0.087 & 0.35 & -0.084 \\
\hline TIER1 & & & & & & & & & & & & & 1 & 0.253 & 0.085 & -0.2 & \begin{tabular}{|l|}
0.057 \\
\end{tabular} & -0.07 & 0.137 & \begin{tabular}{|l|}
-0.439 \\
\end{tabular} & -0.495 & -0.062 & -0.713 & -0.039 & 0.092 & 0.007 \\
\hline ROAA & & & & & & & & & & & & & & 1 & 0.203 & -0.11 & \begin{tabular}{|l|}
0.204 \\
\end{tabular} & -0.22 & -0.21 & -0.222 & 0.089 & -0.068 & -0.009 & -0.022 & -0.253 & 0.125 \\
\hline DIV & & & & & & & & & & & & & & & 1 & -0.19 & \begin{tabular}{|l|}
-0.13 \\
\end{tabular} & -0.06 & -0.12 & -0.252 & -0.211 & -0.084 & -0.153 & -0.049 & -0.012 & -0.049 \\
\hline PB & & & & & & & & & & & & & & & & 1 & 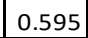 & 0.175 & 0.01 & 0.384 & 0.096 & 0.313 & 0.253 & -0.235 & -0.049 & -0.056 \\
\hline $\mathrm{TQ}$ & & & & & & & & & & & & & & & & & 1 & \begin{tabular}{|l|}
0.285 \\
\end{tabular} & 0.042 & 0.022 & \begin{tabular}{|c|}
-0.019 \\
\end{tabular} & -0.004 & -0.046 & -0.376 & 0.187 & -0.055 \\
\hline SLACK & & & & & & & & & & & & & & & & & & 1 & -0.02 & 0.409 & 0.239 & 0.129 & 0.119 & -0.133 & 0.041 & -0.183 \\
\hline DG & & & & & & & & & & & & & & & & & & & 1 & -0.086 & -0.104 & 0.009 & -0.225 & 0.013 & 0.203 & 0.065 \\
\hline CRSESE & & & & & & & & & & & & & & & & & & & & 1 & 0.636 & 0.197 & 0.602 & 0.041 & -0.235 & -0.079 \\
\hline LNTA & & & & & & & & & & & & & & & & & & & & & 1 & 0.062 & 0.608 & 0.079 & -0.369 & -0.068 \\
\hline CVNI & & & & & & & & & & & & & & & & & & & & & & 1 & 0.232 & -0.018 & -0.241 & -0.048 \\
\hline LEV & & & & & & & & & & & & & & & & & & & & & & & 1 & 0.101 & -0.459 & -0.046 \\
\hline $\mathrm{DE}$ & & & & & & & & & & & & & & & & & & & & & & & & 1 & -0.109 & 0.419 \\
\hline OPAQUE & & & & & & & & & & & & & & & & & & & & & & & & & 1 & -0.044 \\
\hline
\end{tabular}




\section{RESULTS AND DISCUSSION}

Table 5 reports results of OLS (Model-1) ${ }^{7}$ and 3SLS (Model-2) for GCC financial institutions in relation to UAE. Most of the coefficients were highly significant in 3SLS compared to single equation (Model-1). Akaike Information Criterion $(\mathrm{AIC})^{8}$ was generally lower in all three equations in Model-2 compared to Model 1 , signifying gain in efficiency in joint estimation as conceptualized in the framework (figure-1). Also, the covariance of error terms is non-zero in 3SLS confirming that the system of equations is jointly interdependent. Thus our framework is plausible and first null hypothesis is validated. That is, it is not true that ERM \&CG initiatives are not jointly undertaken by the firm, implying there is simultaneity in adopting these initiatives by the BOD. Therefore, the discussion is focused on 3SLS model results.

Table 5. Model results (GCC)

\begin{tabular}{|c|c|c|c|c|}
\hline Variable & $\begin{array}{l}\text { Coefficient } \\
\text { Model-1 (GCC }\end{array}$ & $\begin{array}{l}\text { T-stat } \\
\text {-OLS) }\end{array}$ & $\begin{array}{l}\text { Coefficien } \\
\text { Model-2 (G }\end{array}$ & $\begin{array}{l}\text { T-stat } \\
-3 S L S)\end{array}$ \\
\hline \multicolumn{5}{|c|}{ 1. ERM Equation } \\
\hline Constant & .6241 & 5.11 & 2.6979 & 9.44 \\
\hline FV (Firm Value) & -.0003 & -.89 & .0004 & .93 \\
\hline BOD (Corporate & & & $.0046^{* \star *}$ & 2.75 \\
\hline Governance) & .0014 & .99 & & \\
\hline 2008 & .0176 & .63 & .0391 & 1.19 \\
\hline Bahrain & .0072 & .28 & $-.1393^{\star * *}$ & -4.23 \\
\hline Kingdom of Saudi Arabia & $-.0819^{* \star \star}$ & -2.45 & -.0109 & -.27 \\
\hline Kuwait & .0355 & 1.23 & -.0254 & -.74 \\
\hline Oman & 0.0407 & 1.34 & $-.1320^{* * *}$ & -3.37 \\
\hline Qatar & 0.0024 & 0.08 & $-.1113^{* * *}$ & -2.86 \\
\hline NPL/GL & $0.0003^{* * *}$ & 11.17 & $.0004^{* * *}$ & 11.86 \\
\hline Tier-1 Cap & $0.0008^{* * *}$ & 2.92 & $.0003^{* * *}$ & 6.95 \\
\hline ROAA & -0.0009 & -0.71 & $-.0003^{* * *}$ & -2.03 \\
\hline MB & $0.0005^{* * *}$ & 2.42 & $.0007^{* * *}$ & 3.12 \\
\hline DG & $-0.0005^{\star \star *}$ & -2.01 & -.0002 & -.81 \\
\hline LNTA & $0.0163^{\star *}$ & 1.84 & $-.1203^{* * *}$ & -6.26 \\
\hline LEVERAGE & $0.1117^{\star \star}$ & 1.85 & $.2426^{\star * *}$ & 3.38 \\
\hline OPAQUE & $-0.3953^{* * *}$ & -4.89 & $-.2818^{\star * *}$ & -3.03 \\
\hline CVNI & $0.0083^{* * *}$ & 3.58 & $.0151^{* * *}$ & 5.474 \\
\hline SLACK & $0.2679^{* * *}$ & 5.66 & $.1613^{* * *}$ & 2.93 \\
\hline DIVERSE & $-0.0329^{* *}$ & -1.75 & $.0538^{\star *}$ & 2.29 \\
\hline UAE2008 & $-0.1178^{* *}$ & -2.17 & $-.1578^{* * *}$ & -2.49 \\
\hline AIC (Akaike Info Criteria) & -3.07 & & -2 & \\
\hline $\begin{array}{l}\text { Likelihood ratio statistical } \\
\text { significance } \mathrm{Chi}^{2}\end{array}$ & 1042.13 & & 802 & \\
\hline \multicolumn{5}{|c|}{ 2. Firm Value (FV-Tobin-Q) Equation } \\
\hline Constant & -13.9008 & -3.31 & -18.6144 & -4.29 \\
\hline 2008 & -1.8809 & -0.647 & -1.8223 & -.63 \\
\hline Bahrain & 2.3529 & 0.896 & 2.0751 & .79 \\
\hline Kingdom of Saudi Arabia & -1.5636 & -0.473 & -1.7519 & -.534 \\
\hline Kuwait & 0.4744 & 0.168 & .4709 & .169 \\
\hline Oman & 0.5387 & 0.173 & .0366 & .01 \\
\hline Qatar & -0.3302 & -0.103 & -.5443 & -.17 \\
\hline BOD (Corporate & & & .1435 & .98 \\
\hline Governance) & 0.0529 & 0.359 & & \\
\hline ERM FUNCTION & 1.0697 & 0.306 & 4.9499 & 1.39 \\
\hline GGL & $-0.0132^{* * *}$ & -3.797 & $-.0135^{\star \star \star}$ & -3.95 \\
\hline
\end{tabular}

\footnotetext{
7 The disadvantage of single equation modelling of firm value (Tobin's Q) as a function of ERM and other value determinants is that, it ignores potential selectivity bias that arises due to the likely endogeneity of ERM choice. In other words, some of the factors that are correlated with the firm's choice to adopt ERM may also be correlated with observed differences in Tobin Q. To deal with this potential endogeneity bias, we use a maximum-likelihood treatment in 3SLS model that jointly estimates the decision to engage in ERM and the effect of that decision on Tobin's $Q$ in a system of equations.

${ }^{8}$ Lower AIC (Akaike Information Criteria) is preferred for model selection. http://dx.doi.org/xxxx-xxxxx-xxxx-xxxx
}

(c) 2018 the Authors. Production and hosting by Avicenna FZ LLC. on behalf of Dubai Business School, University of Dubai - United Arab Emirates. This is an open access article under the CC BY-NC license. 


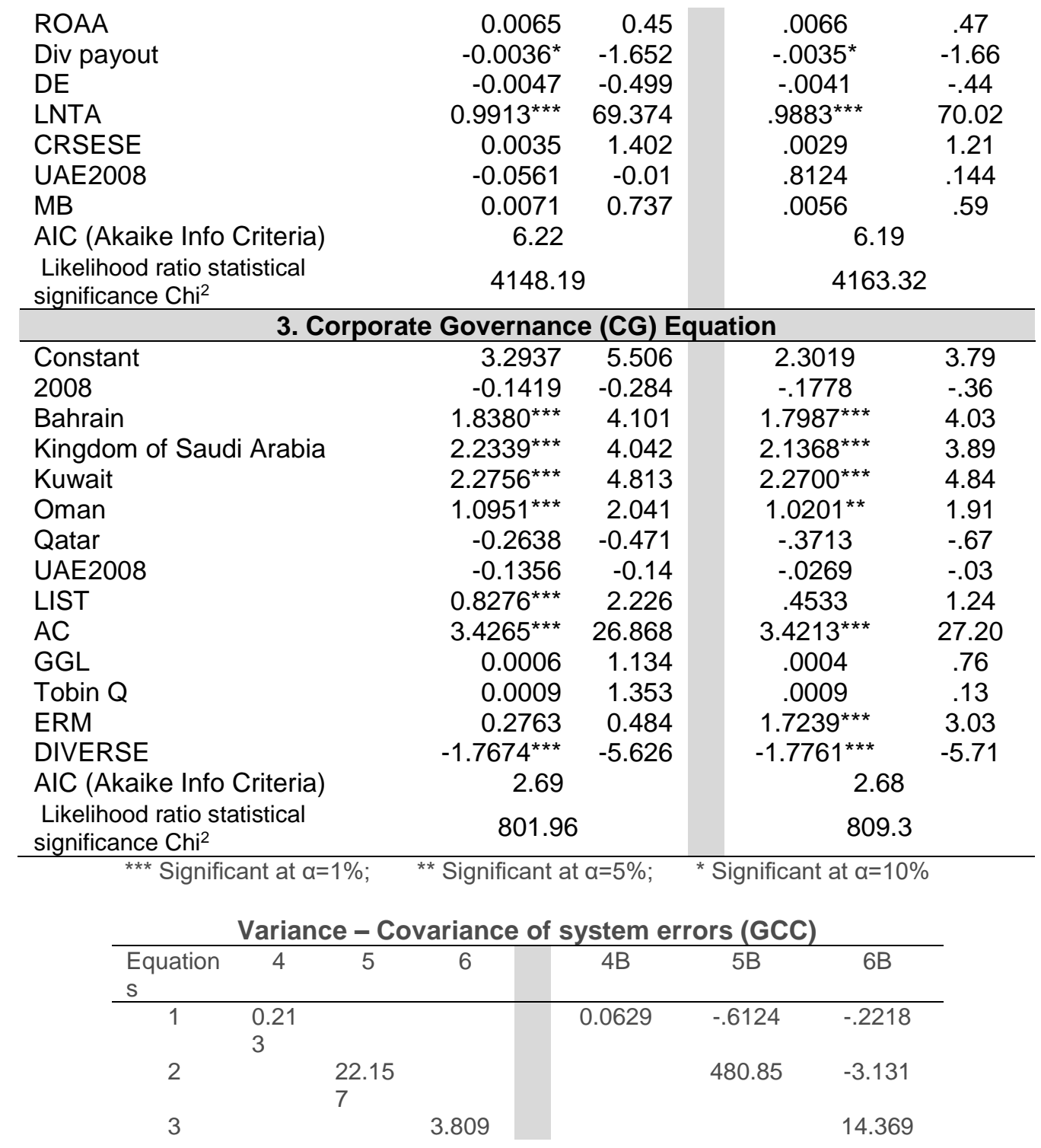

\subsection{ERM Initiative}

Relative to UAE, financial institutions in Bahrain, Oman and Qatar adopted ERM initiative less vigorously during the study period. This observation is statistically highly significant. During crisis period (2008) the ERM adoption in UAE decreased by around $0.16 \%$ and was statistically highly significant. Firm value did not significantly impact adoption of ERM initiative in GCC firms. However, active CG had a significant positive impact on adoption of ERM initiative in GCC firms.

As hypothesized, ERM function is positively related to loan loss reserves, Tier-1 Capital, market price to book ratio, leverage, variability in net income, slack (liquidity) and diversity of operations. Of these significant determinants, leverage, slackness (or liquidity), diversification and variability of earnings had higher magnitude of positive impact on ERM initiative.

A one percent increase in leverage triggered ERM adoption by $0.24 \%$. This is consistent with the finding of Liebenberg and Hoyt (2003) that firms with greater financial leverage are more likely to adopt ERM.

A one percent increase in liquidity (slack) triggered ERM adoption by around $0.16 \%$. This is consistent with the findings of Pagach and Warr (2010) who argue that ERM users may have higher levels of financial slack due to the emphasis on risk management for reducing the probability of financial distress.

A one percent increase in diversity of operations triggered ERM adoption by $0.05 \%$. As hypothesized, diversified firms face a more complex range of risks than do undiversified firms. In the current study, the negative relation 
may point to the fact that diversification may reduce performance as it exacerbates agency costs and leads to inefficient cross-subsidization of poorly performing businesses and thus increases potential for ERM initiative.

A one percent increase in variability in net income triggered ERM adoption by $0.015 \%$. Firms that are relatively more volatile are likely to benefit from the effects of an ERM program.

The magnitude of positive impact of following determinants was less on ERM initiative although they were statistically significant.

A one percent increase in loan loss reserve ratio in gross loan triggered ERM adoption by $0.00042 \%$. A higher loan reserve represents conservative behavior of financial institutions to overcome credit risk and hence this positive relation is plausible.

A one percent increase in tier-1 capital ratio triggered ERM adoption by $0.00026 \%$. Higher tier-1 capital represents a conservative regulatory requirement to overcome capital risk. Hence hypothesis of positive sign on the estimated coefficient is plausible.

A one percent increase in market price to book ratio triggered ERM adoption by $0.0007 \%$. This represents the fact that investors value favourably the financial institutions that adopt ERM as risk management strategy.

The degree of ERM adoption was higher due to the prevailing risk determinants such as leverage risk, liquidity risk, diversity of operations, and variability of net income, and to a lesser extent by default risk and capital risk in the financial institutions in GCC.

ERM function was significantly negatively related to opaqueness, size, and profitability of financial institutions in GCC. Unexpectedly the opaque variable showed negative relation implying that, relative to UAE other financial institutions in GCC with less intangible assets (less opaque) in their asset structure adopted ERM in their operations more vigorously compared to financial institutions with large intangible assets. A $1 \%$ reduction in opaqueness of financial institutions improved ERM adoption by $0.2818 \%$. This finding is also in contrast to Pagach and Warr (2010) who stated that ERM adoption is related to the opacity of a firm's assets because assets that are relatively more opaque are more difficult to liquidate in order to avert financial distress.

The size variable also showed negative relation and were highly significant probably implying that small size GCC firms adopted ERM in their operations more vigorously compared to large size financial institutions. A $1 \%$ reduction in the size (in assets) of financial institutions improved ERM adoption by $0.12 \%$. This finding is in contrast to the survey evidence that larger firms are more likely to engage in ERM because they are more complex, face a wider array of risks, and have the institutional size to support the administrative cost of an ERM program (Colquitt, Hoyt, and Lee, 1999; Hoyt, Merkley, and Thiessen, 2001; Beasley, Clune, and Hermanson, 2005; Standard \& Poor's, 2005). Similarly, a one percent increase in profitability of operations triggered reduction in ERM adoption by $0.0003 \%$, implying that adoption of ERM entailed significant capital expenditure resulting in reduced profitability.

\subsection{Firm Value (FV) Function}

Equation 2 in Table 5 explains the firm value function of GCC financial institutions. Consistent with the framework (Figure 1), the ERM \& CG initiative has a joint positive impact on firm value in GCC although they were statistically less significant.

Firm value also increased with the size of financial institutions. A one percent increase in the size of financial institutions increased the firm value by $0.988 \%$ and was statistically very significant. However, Lang and Stulz (1994) and Allayannis and Weston (2001) find a significantly negative relation between size and firm value in their studies.

Unexpectedly, firm value was negatively related to growth of GCC financial institutions. A one percent increase in growth rate of financial institutions reduced the firm value by $0.0135 \%$ and was highly significant. One can however argue that, increased growth rate might imply potential future growth opportunities in time $t+1$ for which the firm has to commit funds in time $t$, with the result there is reduced capital available in time $t$ for firm's operations and hence firm value is reduced in time $t$. 
A one percent increase in dividend payout also decreased the firm value by $0.0035 \%$ and was statistically significant at $6 \%$ level. This is plausible since investors may view a disbursement of cash in the form of a dividend as a sign that GCC firms have exhausted their growth opportunities and hence the payment of dividends will negatively affect firm value.

Other determinants such as Profitability, Leverage, Cost efficiency of operations, Market price to book ratio and distress period in UAE (UAE-2008) were not significant determinants of firm value of GCC financial institutions.

\subsection{Corporate Governance (CG) Initiative}

Equation 3 in Table 5 explains the CG initiative in GCC financial institutions. The results suggest that corporate governance mechanism was active in financial institutions in Bahrain, Saudi Arabia, Kuwait and Oman relative to UAE financial institutions. While the listing of financial institutions in GCC did not significantly impact governance of GCC financial institutions, the existence of audit committees shows a significant positive impact on the governance of GCC financial institutions. Economic crisis in UAE in 2008 did not impact CG initiative of GCC financial institutions.

Interestingly, ERM adoption in GCC financial institutions has shown a significant positive influence on governance mechanism in GCC. A one percent increase in ERM initiative impacted corporate governance of GCC financial institutions by $1.7239 \%$. This is statistically highly significant. This result implies that GCC firms' BOD derived greater benefits from ERM adoption in their firms.

As expected, CG initiative was positively impacted by existence of audit committees in the BOD of GCC financial institutions. A $1 \%$ increase in existence of audit committees resulted in around $3.42 \%$ improvement in CG initiative. SOX Act identifies existence of audit committee in the BOD as a good feature of active governance. To that extent the system model results indicate that consistent with SOX Act, GCC financial institutions exhibited active corporate governance.

The governance was however highly significantly and negatively related to diversity of operations of GCC financial institutions. A one percent increase in diversity of operations in GCC financial institutions outside the GCC borders reduced governance efficacy by around 1.78 percent. This is plausible since diversification may increase agency costs and lead to inefficient cross-subsidization of poorly performing businesses (Easterbrook, 1984; Berger and Ofek, 1995), due to the prevailing economic uncertainty in neighboring Arab countries owing to Arab Spring. Other variables such as Growth, and Firm Value did not impact CG of GCC financial institutions.

In summary, the results in Table 5 and non-zero covariance of error terms across three equations rejects the null hypothesis that the Equations (1), (2) and 3 are independent and supports endogeneity of ERM, CG initiatives on firm values through their joint estimation. Thus, the second research null hypothesis is not true i.e., independence between firm value, CG and ERM initiatives is not true.

\section{CONCLUSIONS AND LIMITATIONS}

\subsection{Conclusions}

One of the major challenges facing researchers is how to identify firms that engage in ERM \& CG that add value to the firms. The study designs a framework (figure 1) to model the simultaneity and jointness of Corporate Governance, ERM decisions on Firm Value, and to provide empirical evidence on the quantitative and joint impact of ERM \& CG initiatives on firm value of financial institutions in GCC. In the absence of explicit disclosure of ERM implementation \& CG initiatives, we use an indicator variable for a variety of "if" conditions for proxying ERM \& CG. For ERM, the alternative condition is any one of the stated condition namely: if the financial firm has various committees (including audit committee) in the BOD (BOD); if the financial firm has derivative products under assets/liabilities; if the financial firm maintains a positive reserve ratio of non-performance loans to gross loans; if the financial firm has tier-1 Capital Adequacy Ratio greater than 4\%. CG initiative is similarly modeled as an indicator variable if there is presence of audit committees in the BOD, existence of decisions on dividend payment by the BOD, and if the firms are publicly listed; all these conditions reflect components of active corporate governance mechanism. Tobin- $Q$ measure proxies Firm value in GCC.

The hypotheses that there exists simultaneity and endogeneity in corporate governance (through CG and ERM initiatives) and firm value are tested through modelling a system of $3 S L S$ equation system. The non-zero cross 
equation error confirms that the system of three equations is interdependent and there was simultaneity in CG, ERM and Firm Value determinants. Lower Akaike Information Criteria (AIC), Likelihood ratio test with highly significant $\mathrm{Chi}^{2}$ values further confirm the endogeneity of CG, ERM and Firm Value determinants.

3SLS results indicate that relative to UAE, financial institutions in Bahrain, Oman and Qatar significantly less rigorously adopted ERM initiative during 2004-2011. During 2008 crisis period the ERM adoption in UAE decreased by $0.16 \%$ and was statistically highly significant.

ERM was significantly dependent on: Risk Characteristics (measured by variance in net income or variance in market price per share); Financial characteristics (measured by Leverage, Cash availability (slack), Profitability); Asset characteristics (measured by opaque (intangible) assets in total assets, growth options), Market characteristics (measured by Market to Book ratio); and Firm risk characteristics (measured by Tier-1 Capital, Loan loss reserve, Market to book ratio). Firm value was dependent on: Growth, Dividend pay-out, and Size. Similarly, Corporate Governance (CG) was dependent on: ERM, Existence of Audit committee (in BOD), and diversity in operations. Of these significant determinants, higher magnitude of positive impact on ERM initiative was seen in leverage $(0.24 \%)$, liquidity $(0.16 \%)$, diversification $(0.05 \%)$ and variability of earnings $(0.015 \%)$. Loan loss reserves, tier-1 capital ratio and market to book price had statistically significant but very minor positive impact on ERM initiative. Unexpectedly, ERM initiative was significantly and negatively impacted by determinants such as less opaqueness $(0.28 \%)$, size of the firm $(0.12 \%)$ and profitability $(0.0003 \%)$.

The system model results further indicate that firm value is jointly and positively impacted by ERM \& CG initiatives on GCC financial institutions although the impact was less statistically significant. Firm value did not significantly improve during 2004-11 in GCC countries. However, firm size was the only determinant that significantly and positively impacted $(0.988 \%)$ firm value. Other determinants such as growth $(0.0135 \%)$ and dividend pay-out $(0.0035 \%)$ had a significant negative impact on firm value in GCC.

Relative to UAE the corporate governance mechanism was active in Bahrain, Saudi Arabia, Kuwait and Oman firms. Further, the existence of audit committees in the GCC firm's boards and ERM adoption showed significant positive impact on corporate governance by $3.42 \%$ and $1.7239 \%$ respectively in GCC. On the other hand, corporate governance mechanism was significantly less inclined to encourage diversity of firms' operations as the GCC boards were more apprehensive that their efficacy would decline by around 1.78 for every $1 \%$ increase in diversity of operations outside GCC borders.

This study is possibly the first study to document the value relevance of ERM and CG initiatives on GCC firms' value. This research analysis provides a starting point for additional research into ERM, Governance and Firm value in neighbouring AGCC, MEA and other developing economies. The vast majority of extant research takes the form of surveys. These studies are valuable as a source of descriptive information regarding ERM \& CG use but do not answer the fundamental question of whether ERM \& CG enhances firm value, which is addressed in this study using a reasonably good methodology and data set that are readily available to most researchers.

\subsection{Limitations}

Relatively small sample size, small GCC economies, and inability to measure the intensity of ERM \& CG usage in GCC firms are some of the limitations in our study. These limitations may reduce the extent to which the results may be generalized. As such, additional research using larger samples by extending to AGCC (Arab GCC) countries and more refined ERM \& CG measures would represent an important broader generalizable contribution to the emerging literature on ERM, CG and firm value.

\section{REFERENCES}

Allayannis, G., and J. Weston (2001). The Use of Foreign Currency Derivatives and Firm Market Value. Review of Financial Studies, 14: 243-276.

A.M. Best, 2006, A.M. Best Comments on Enterprise Risk Management and Capital Models, World Wide Web: http://www.ambest.com/ratings/ methodology/enterpriserisk.pdf.

Beasley, M. S., R. Clune, and D. R. Hermanson, 2005, Enterprise Risk Management: An Empirical Analysis of Factors Associated with the Extent of Implementation, Journal of Accounting and Public Policy, 24: 521-531

Beasley, M. S., D. Pagach, and R. Warr, 2008, The Information Conveyed in Hiring Announcements of Senior Executives Overseeing Enterprise-Wide Risk Management Processes, Journal of Accounting, Auditing, and Finance, 23: 311332.

Berger, P. G., and E. Ofek, 1995, Diversification's Effect on Firm Value, Journal of Financial Economics 37: 39-65. 
Boatright, J.R. (2011). Risk Management and the Responsible Corporation: How Sweeping the Invisible hand? Business and Society Review, 116 (1): 145-170.

Boone, A., Field, L., Karpoff, J., Raheja, C. G., 2007. The determinants of corporate board size and composition: An empirical analysis. Journal of Financial Economics 85, 66-101.

Colquitt, L. L., R. E. Hoyt, and R. B. Lee, 1999, Integrated Risk Management and the Role of the Risk Manager, Risk Management and Insurance Review, 2: 43-61.

Committee of the Sponsoring Organizations of the Treadway Commission (2004). Enterprise Risk Management, Integrated Framework (COSO-ERM Report). New York: AICPA.

Cummins, J. D., C. Lewis, and R. Wei, 2006, The Market Impact of Operational Risk Events for U.S. Banks and Insurers, Journal of Banking and Finance, 30: 2605-2634.

Easterbrook, F. H., 1984, Two Agency-Cost Explanations of Dividends, American Economic Review, 74: 650-659.

Fama, E. F., Jensen, M. C., 1983. Separation of ownership and control. Journal of Law and Economics 26, $301-326$.

Guay, W. and S. P. Kothari, 2003, How Much Do Firms Hedge With Derivatives?, Journal of Financial Economics, 70: 423461.

Gumming, C. M., and B. J. Hirtle, 2001, The Challenges of Risk Management in Diversified Financial Companies, FRBNY Economic Policy Review, 7: 1-17.

Harris, M., Raviv, A., 2008. A theory of board control and size. Review of Financial Studies 21, 1797-1832.

He, E., D.W. Sommer and X. Xie, 2011, The Impact of CEO Turnover on Proerty/Liability Insurer Performance, Journal of Risk and Insurance, 78(3):583-608.

Hermalin, B. E., Weisbach, M. S., 1998. Endogenously chosen boards of directors. American Economic Review 88, 96118.

Hoyt, R. E., B. M. Merkley, and K. Thiessen, 2001, A Composite Sketch of a Chief Risk Officer, The Conference Board of Canada, Toronto, September.

Jensen, M. C., 1986, Agency Costs of Free Cash Flow, Corporate Finance and Takeover, American Economic Review, 76 : 323-329.

Kleffner, A., R. Lee, \& McGannon, B. (2003). The effect of corporate governance on the use of enterprise risk management: Evidence from Canada. Risk Management and Insurance Review 6 (1): 53-73.

Lam, J. (2001). The CRO is here to stay. Risk Management, 48 (4) (April), 16-22

Lang, L. and R. Stulz, 1994, Tobin's Q, Diversification, and Firm Performance, Journal of Political Economy, 102: 12481280.

Lewellen, W. G., 1971, A Pure Financial Rationale for the Conglomerate Merger, Journal of Finance, 26: 521-537.

Liebenberg, A. \& Hoyt, R. (2003). The determinants of enterprise risk management: evidence from the appointment of chief risk officers, Risk Management and Insurance Review 6 (2003) (1), pp. 37-52.

Lindenberg, E. and S. Ross, 1981, Tobin's Q Ratio and Industrial Organization, Journal of Business, 54: 1-32.

Lehn, K., Patro, S., Zhao, M., 2009. Determinants of the size and composition of corporate boards: 1935-2000. Financial Management 38, 747-780.

Linck, J. S., Netter, J. M., Yang, T., 2008. The determinants of board structure. Journal of Financial Eco nomics 87, 308328.

Meulbroek, L. K., 2002, Integrated Risk Management for the Firm: A Senior Manager's Guide, Journal of Applied Corporate Finance, 14: 56-70.

Miccolis, J., and S. Shah, 2000, Enterprise Risk Management: An Analytic Approach, Tillinghast-Towers Perrin Monograph (New York).

Niamh M. Brennan and Jill Solomon (2008). Accounting, Auditing \& Accountability Journal (2008), Corporate Governance, accountability and mechanisms of accountability: an overviewVolume 21 , No.7, pp 885-906,

Nocco, B. W. \& Schulz, R. (2006). Enterprise risk management: Theory and practice. Journal of Applied Corporate Finance, $18(4)$, pp. 8-20(13)

Pagach, D. P. \& Warr, R. S. (2007). An Empirical Investigation of the Characteristics of Firms Adopting Enterprise Risk Management. Working paper, Available at SSRN: http://ssrn.com/abstract $=1010200$

Pagach, D., and R. Warr, 2010, The Effects of Enterprise Risk Management on Firm Performance. World Wide Web: http://ssrn.com/abstract=1155218 (accessed April 10, 2010).

Pohle, G. and Hittner, J. 2008. Attaining Sustainable Growth Through CSR, IBM Institute for Business Value.

Potter, S.W., and Sommer, D.W. (2006), Opaqueness in the Insurance Industry: Why are Some Insurers Harder to Evaluate Than Others? Risk Management and Insurance Review, 9:149-163

PricewaterhouseCoopers (2008): Does ERM matter? ERM for the Insurance Industry: http://www.pwc.com/en GX/gx/insurance/pdf/erm highlights.pdf

PricewaterhouseCoopers (2010): CTC Guide to ERM Beyond Theory: Practitoner Perspectives on ERM. http://www.pwc.com/us/en/risk-management/assets/beyond-theory.pdf 
Raheja, C. G., 2005. Determinants of board size and composition: A theory of corporate boards. Journal of Financial and Quantitative Analysis 40, 283-306.

Sim Segal (2011) Corporate Value of Enterprise Risk Management: The Next Step in Business Management (Wiley Corporate F\&A); ISBN-13: 978-0470882542

Smithson, C. and B. J. Simkins, 2005, Does Risk Management Add Value? A Survey of the Evidence, Journal of Applied Corporate Finance, 17: 8-17.

Standard \& Poor's, 2005, Insurance Criteria: Evaluating The Enterprise Risk Management Practices of Insurance Companies, October 17.

Teece, D. J., 1980, Economies of Scope and the Scope of the Enterprise, Journal of Economic Behavior and Organization, 1: 223-247.

Yermack, D., 1996. Higher market valuation of companies with a small BOD. Journal of Financial Economics 40, $185-211$.

Yilmaz, A.K., and Flouris, T. 2010. Managing Corporate sustainability: Risk Management Process Based Perspective. African Journal of business Management. 4(2):162-171. 